\title{
The Significance of Certain Food Substances for Plant Growth.
}

\author{
BY \\ W. B. BOTTOMLEY, M.A. \\ Professor of Botany, University of London, King's College.
}

With two Figures in the Text.

F VIDENCE has been rapidly accumulating during recent years which proves that the soluble humus of the soil is an essential factor of soil
fertility, providing not only food and energy for numerous soil bacteria, but also serving as a source of food for plants. A mongst numerous investigators may be mentioned Krzemieniewski (1), who demonstrated that soil humates have a stimulating influence on the fixation of nitrogen by nitrogen-fixing bacteria, and Hutchinson and Miller (2), who have shown that soil humates can also be readily assimilated by plants, and serve as a source of nitrogen.

During a search made during the summer of 1912 to find a material rich in soluble humates, to serve as a medium for the growth and distribution of nitrogen-fixing organisms, it was discovered that when peat is submitted to the action of certain aerobic soil organisms at a temperature of $26^{\circ} \mathrm{C}$, it is rapidly decomposed, and a large amount of the humic acid present is converted into soluble ammonium humate.

This 'bacterized' peat, after being sterilized, was found to be an excellent medium in which to grow nitrogen-fixing bacteria and apply them to the soil. Mixed with soil in the proportion of $9 \mathrm{oz}$. of soil to $\mathrm{I} \mathrm{oz}$. of bacterized peat, saturated with a mixed culture of nitrogen-fixing organisms, a large increase in the nitrogen content of the soil was obtained after being kept in an incubator for seventeen days at a temperature of $26^{\circ} \mathrm{C}$., as shown by the following tables :

\section{Plumstead soil.}

Soil plus sterilized bacterized peat $(a) 0.7 \mathrm{I} 7 \mathrm{grm} . \mathrm{N}$ per $\mathrm{I} 00 \mathrm{grm}$. soil.

Soil plus active bacterized peat

(b) 0.709

(a) 0.792

(b) 0.789

,

,

,

An average gain of $77 \mathrm{mg}$. of $\mathrm{N}$ per 100 grm. soil. 


\section{Rothamsted soil.}

Soil plus sterilized bacterized peat $(a) 0.367 \mathrm{grm}$. N per $100 \mathrm{grm}$. soil.

Soil plus active bacterized peat

(b) $0.3^{6} 3$

(a) 0.421

(b) 0.417

An average gain of $54 \mathrm{mg}$. of $\mathrm{N}$ per $100 \mathrm{grm}$. soil.

It was also found (3) that an aqueous extract of the bacterized peat (one part peat to 200 partswater) supplied all the plant food necessary for water-cultures with tomato, barley, and buck-wheat seedlings.

Experiments conducted at Kew Gardens and Chelsea Physic Garden during the summer of last year (I9I3) on various pot plants-wheat, barley, oats, maize, salvia, fuchsia, carnation, primula, \&c.-demonstrated that the bacterized peat possessed a certain growth-stimulating property which could not be accounted for by any known manurial constituents present (4). Further experiments showed that this stimulating substance was soluble in water and effective in very minute quantities. Dr. Rosenheim, in an experiment with seedlings of Primula malacoides potted up in loam, leaf mould, and sand, found that plants watered twice with the water extract of only $0.18 \mathrm{grm}$. of bacterized peat were, after six weeks' growth, double the size of similar untreated plants, and it was noted that flower production and root development were promoted equally with increase of foliage.

These results suggested that the growth-stimulating action of the bacterized peat might be due to the presence of substances similar in nature to the accessory food bodies concerned in animal nutrition.

Recent work on animal metabolism has shown that animals cannot live on a diet of pure proteins, carbohydrates, fats, and inorganic salts alone. In addition very small amounts of certain other organic compounds, the so-called accessory food bodies, are absolutely essential for normal nutrition and growth.

These substances were first recognized in connexion with the diseases of beri-beri and scurvy, which are caused by a deficiency in diet of minute amounts of certain nitrogenous substances necessary for normal metabolism. They have been obtained chiefly from vegetable tissues-rice polishings, wheat, barley, lentils, yeast, fresh vegetables, and fruits; amongst animal tissues from milk, egg-yolk, and ox brain.

More recently the researches of Osborn and Mendel (5) and Hopkins (6) have demonstrated the importance of small amounts of similar accessory food substances in the metabolism of growing animals. These investigators have shown that young rats fed on a dietary consisting of a mixture of pure proteins, carbohydrates, fats, and inorganic salts failed to grow, but on the addition of a very small amount of certain substances obtained from milk growth was normal. 
Very little is known at present as to the nature and composition of these substances. The all-important practical point is that their existence and action have been proved. Unfortunately the active substance appears to be largely destroyed by chemical manipulations, and it is difficult to obtain sufficient to study its chemical constitution and properties.

Cooper and Funk (7) were the first to show that the curative substance for beri-beri is precipitated by phosphotungstic acid from an aqueous solution of an alcoholic extract of rice polishings. Later Hopkins found that the active growth-substance in his experiments could be obtained from the phosphotungstic acid precipitate of proteid-free milk. Funk (8), by a complex fractionation of the phosphotungstic precipitate of anti-beri-beri substance, succeeded in isolating a substance melting at $233^{\circ} \mathrm{C}$, which he called vitamine, and which, in amounts of 0.02 to $0.04 \mathrm{grm}$., cured polyneuritis in pigeons. This substance he considered to be of the nature of a pyrimidine base. Hopkins (9), however, states that the additions in his growth experiments were free from amino acids, purine, and pyrimidine bases.

At present the only definite statement that can be made concerning these bodies is that they are similar in being precipitated by phosphotungstic acid, and in being active in very minute amounts. It has been suggested that they belong to a new group of nitrogenous compounds, which exist only in small amounts in food materials, but are so extremely active that minute quantities are sufficient to supply the needs of the organism.

As previously stated, the growth results obtained with a water extract of bacterized peat suggested that the peat might contain substances similar to these accessory food bodies. Water and sand cultures of wheat seedlings were therefore commenced to test this hypothesis. The first experiment was made to determine how far the phosphotungstic acid fraction of bacterized peat extract was effective in stimulating plant-growth. The bacterized peat was extracted with absolute alcohol in a shaking machine for three hours, and the extract evaporated to dryness in vacuo.

The residue was taken up in distilled water, filtered, and to the filtrate sulphuric acid was added until the concentration of the latter reached 5 per cent. A slight precipitate of humic acid was filtered off, and to the filtrate an excess of a 30 per cent. solution of phosphotungstic acid was added. The whole was then left to stand overnight, when the liquid was decanted off through a filter, the precipitate repeatedly washed with a 5 per cent. solution of sulphuric acid, and finally decomposed with an excess of baryta. The liquid was filtered off from the precipitate of barium phosphotungstate, and the filtrate, freed from the last traces of baryta by means of a very dilute solution of sulphuric acid, was evaporated to dryness in vacuo. From seven kilos of bacterized peat the amount of dry substance 
obtained from the phosphotungstic acid fraction amounted to I2.0096 grm., and since this was made up for experimental purposes into a solution containing the fraction from Io grm. of peat per litre, the proportion of the dry phosphotungstic acid fraction in the final solution employed consisted of seventeen parts per million. This fraction was tested upon wheat seedlings in conjunction with Detmer's complete food solution. Ten seedlings were germinated in clean sand in each of nine pots, which were arranged in three series of three pots each. Series I was treated with complete food solution, Series II with complete food plus alcoholic extract from Io grm. of peat per litre of solution, and Series III with complete food plus phosphotungstic fraction from $10 \mathrm{grm}$. of peat per litre of solution. The food solution employed contained nitrogen, phosphorus, and potash, estimated as $\mathrm{NH}_{3}, \mathrm{P}_{2} \mathrm{O}_{5}$, and $\mathrm{K}_{2} \mathrm{O}$, in the proportion of 400,200 , and $\mathrm{I}, 220$ parts per million respectively, so that in addition Series III had seventeen parts per million of dry substance obtained from the phosphotungstic fraction. Each pot was treated with 100 c.c. of its solution one week after sowing the seed, and the treatment repeated once weekly for five weeks, at the end of which period the plants were uprooted, washed, dried, and weighed. The results were as follows :

\section{TABLE I.}

\section{Series.}

I. Complete food solution

II. Complete fóod plus alcoholic extract . . .

III. Complete food plus phosphotungstic fraction
Weight of 30 plants.

I I.94 grm.

$14.46 \mathrm{grm}$.

I $5.45 \mathrm{grm}$.
Increase over Series $I$.

$2 \mathrm{I} \cdot \mathrm{I} \%$

The results thus obtained indicate that the substance in bacterized peat which is so effective a stimulant of plant growth is also precipitated by phosphotungstic acid, and that this phosphotungstic fraction is quite as effective as the original alcoholic extract of the peat. Funk found that upon further fractionation of his phosphotungstic acid precipitate with silver nitrate and baryta, and elimination of the reagents, he obtained some relatively pure crystalline substances to which he gave the name 'vitamines', and these he considered to be the specific curative substances. In order to determine how far the growth stimulant in bacterized peat resembled these so-called 'vitamines', a further fractionation was carried out along the lines described in his paper.

The phosphotungstic acid precipitate was decomposed as before described with baryta, and the last traces of baryta eliminated by means of sulphuric acid. To the filtrate from the barium salt, silver nitrate was first added, and then baryta, until no further precipitate was produced. The brownish precipitate was filtered off, well washed, suspended in dilute sulphuric acid, and decomposed with sulphuretted hydrogen. The filtrate from the silver sulphide was then exactly neutralized with baryta, the clear 
liquid filtered off from the precipitate of barium sulphate, and evaporated to dryness in vacuo. The weight of dry substance obtained from the silver fraction from 7 kilos of bacterized peat amounted to $0.245^{2}$ grm., and since this also was made up for experiment into a solution containing the silver fraction from Io grm. of peat per litre, this solution contained the dry substance from the silver fraction in the proportion of 0.35 part per million. This fraction was also tested concurrently with phosphotungstic acid fraction upon wheat seedlings. Fifteen seeds were germinated in each of nine pots, which were arranged in three series of three each. Series I was treated with complete food solution containing nitrogen, phosphorus, and potash, estimated as $\mathrm{NH}_{3}, \mathrm{P}_{2} \mathrm{O}_{5}$, and $\mathrm{K}_{2} \mathrm{O}$, in the proportion of 400 , 200 , and I,220 parts per million respectively. Series II was treated with a similar solution, containing in addition seventeen parts per million of the phosphotungstic fraction, and Series III with the complete food solution plus 0.35 part per million of the silver fraction. The pots were first treated one week after sowing the seed, and after that each pot received once weekly 100 c.c. of its food solution for seven weeks. At the end of that period the plants were washed, dried, and weighed, and after the gross weight had been taken, the plants were all dried in the steam-oven at $100^{\circ} \mathrm{C}$. until their weight was constant.

The results are as follows :

TABLE II.

\begin{tabular}{|c|c|c|c|c|}
\hline Series. & $\begin{array}{l}\text { Gross weight } \\
\text { of } 45 \text { plants. }\end{array}$ & $\begin{array}{c}\text { Increase over } \\
\text { Series } I_{0}\end{array}$ & Dry Weight. & $\begin{array}{c}\text { Increase over } \\
\text { Series } I .\end{array}$ \\
\hline $\begin{array}{l}\text { I. Complete food D } \\
\text { I. Complete food plus phos- }\end{array}$ & & & $13 \cdot 3480 \mathrm{grm}$ & \\
\hline $\begin{array}{l}\text { photungstic fraction } \\
\text { Complete food plus silver }\end{array}$ & $96 \cdot 8 \mathrm{grm}$. & $50 \cdot 0 \%$ & I6.3818 grm. & $22 \cdot 7 \%$ \\
\hline fraction . . . & $9^{6} \cdot 5 \mathrm{grm}$. & $49^{\circ} 6 \%$ & $15 \cdot 714^{8} \mathrm{grm}$. & I7.7\% \\
\hline
\end{tabular}

The silver fraction from the peat extract, corresponding with the 'vitamine' fraction of Funk, having thus given results approaching those of the phosphotungstic fraction, a preliminary investigation was made to test its effect on the growth of wheat seedlings in water culture. Two sets each consisting of eighteen similar seedlings were carefully selected, each set being originally of equal weight, viz. $4.73 \mathrm{grm}$. Each set was divided for purposes of water culture among three similar bottles of 200 c.c. capacity, six plants being inserted through notches in the corks of each bottle, so that the roots dipped into the solution. The three bottles of Set I were filled with Detmer's nutrient solution, made with pure salts in physiologically pure distilled water, in which the proportions of $\mathrm{NH}_{3}, \mathrm{P}_{2} \mathrm{O}_{5}$, and $\mathrm{K}_{2} \mathrm{O}$ were 400,200 , and $\mathrm{I}, 220$ parts per million respectively; while those of Set II contained a precisely similar solution which had received in addition 0.35 part per million of the silver fraction of peat extract. The 
bottles were aerated daily, and the solutions changed twice a week, while at the end of every sixteen or seventeen days the plants were removed, dried, and weighed.

The results obtained are shown in the following table:

\section{TABLE III.}

Series.

I. Pure food solution

II. Pure food solution plus silver fraction
Weight of set of $\mathrm{I} 8$ plants.

Original weight $\quad 4.73 \mathrm{grm}$.

After 16 days $\quad 5^{\circ} 4^{2} \mathrm{grm}$.

After further I' days $5^{\circ} 29$ grm.

After further I 7 days $4^{\circ} 33$ grm.

Original weight $\quad 4.73 \mathrm{grm}$.

After 16 days $\quad 5.57 \mathrm{grm}$.

After further I 7 days 6.65 grm.

After further I 7 days $7 \cdot 33$ grm.
Percentage gain or loss on original weight.

$+14.7 \%$

$+11 \cdot 8 \%$

- $8.4 \%$

$+17.7 \%$
$+40.6 \%$
$+54.9 \%$

The results are graphically represented in Diagram $\mathrm{I}$, in which the dotted line represents the changes in weight of the series in pure food, and the unbroken line shows the progressive increase in weight obtained by addition of the silver fraction.

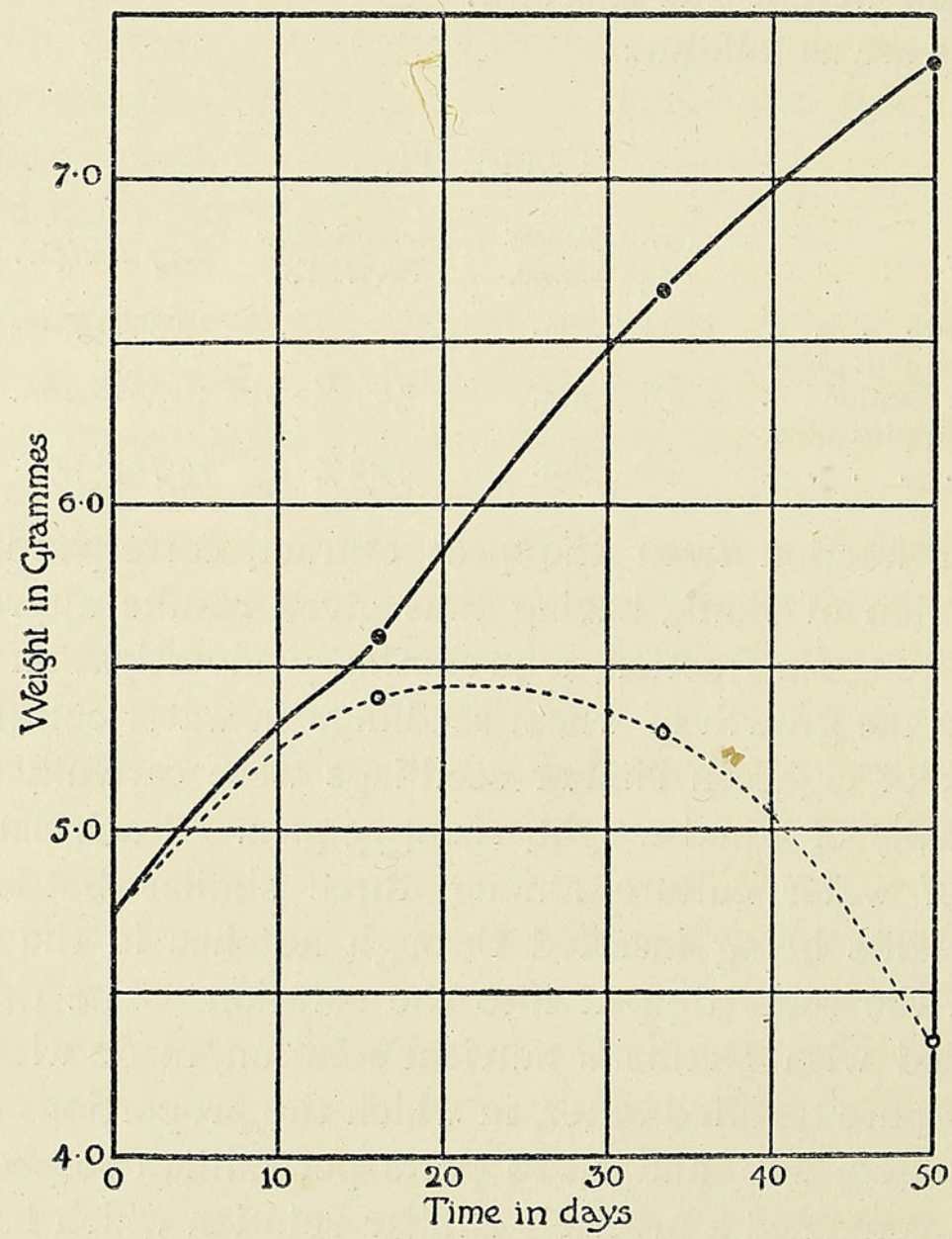

DIAGRAM I. 
The slow growth of the seedlings in this experiment will be noted. This is accounted for by the fact that they were grown in an unheated greenhouse on the roof of King's College from late in February to early in April this year, when there was very little sunshine.

$\mathrm{Up}_{\mathrm{p}}$ to a certain point the two series of plants increased in weight to an almost equal extent. Beyond this point the seedlings growing in pure food solution were unable to utilize the food supplied to them, and gradually withered and died, whilst the seedlings with the silver fraction of bacterized peat extract continued to grow, and were strong and healthy throughout the experiment, their vigour being specially manifest in a welldeveloped root system. It is evident from this experiment that bacterized peat contains a substance or substances which enable the plant to utilize the normal mineral food constituents supplied to it. In nature doubtless this substance or substances are supplied by 'humus'- the decayed organic matter in the soil.

A series of experiments by Fürst (10) in I9I2 on the anti-scorbutic accessory food substances obtained from various seeds is suggestive in connexion with the fact noticed above, that in both series of plants growth was almost equal up to a certain point.

Fürst showed that it was only during germination that the anti-scorbutic substances were developed in seeds of barley, oats, peas, and flax. Guineapigs suffering from scurvy when fed on these seeds before germination soon died, but seeds, soaked in water for twenty-four hours, and then kept in a warm room for two or three days until the young roots began to show, were as effective in curing the disease as extracts from green vegetables.

The development of these substances during germination must have a definite relation to the seed itself, and suggests the possibility of the formation during germination of special growth substances, which enable the young embryo to utilize the food material present in the seed. If this is so, the removal of the source of these growth substances by the cutting off of the seed as soon as possible after germination should render the effect of an addition of such substances in the food solution all the more marked.

In order to test this hypothesis, two series of wheat seedlings, similar to those used above, but in a rather younger state, were taken. Before the removal of their seeds these two sets were of equal weight : viz. $3.97 \mathrm{grm}$. Their seeds were carefully removed, injury to the plants being avoided, and after this process the two sets weighed respectively $3 \cdot 2$ and $3 \cdot 17 \mathrm{grm}$. These were treated in precisely the same manner as before : the first being given complete food salts, and the second food salts with the addition of the silver fraction. The weights of the two sets at various dates are shown in the following table: 


\section{TABLE IV.}

Series.

I. Complete food solution . . . .

II. Complete food solution plus silver fraction .......
Weight of set of 18 plants.

Original weight $3.20 \mathrm{grm}$.

Weight after 16 days $3.37 \mathrm{grm}$.

After further I 7 days $3 \cdot 20 \mathrm{grm}$.

After further 17 days $2.85 \mathrm{grm}$.

Original weight $\quad 3 \cdot 17 \mathrm{grm}$.

After 16 days $\quad 3.63$ grm.

After further $\mathrm{z}$ days $4^{\cdot 29} \mathrm{grm}$.

After further I 7 days $5^{\circ} \circ 5 \mathrm{grm}$.
Percentage gain or loss in weight.

$$
\begin{array}{r}
+5.3 \% \\
+0.0 \% \\
-10.9 \%
\end{array}
$$$$
\begin{aligned}
& +14.5 \% \\
& +35.3 \% \\
& +59.3 \%
\end{aligned}
$$

$+59.3 \%$

Diagram 2 (below) shows the variation in weight of the seedlings throughout the experiment, the dotted curve representing the series in pure food, while the unbroken curve shows the effect of the addition of the silver fraction.

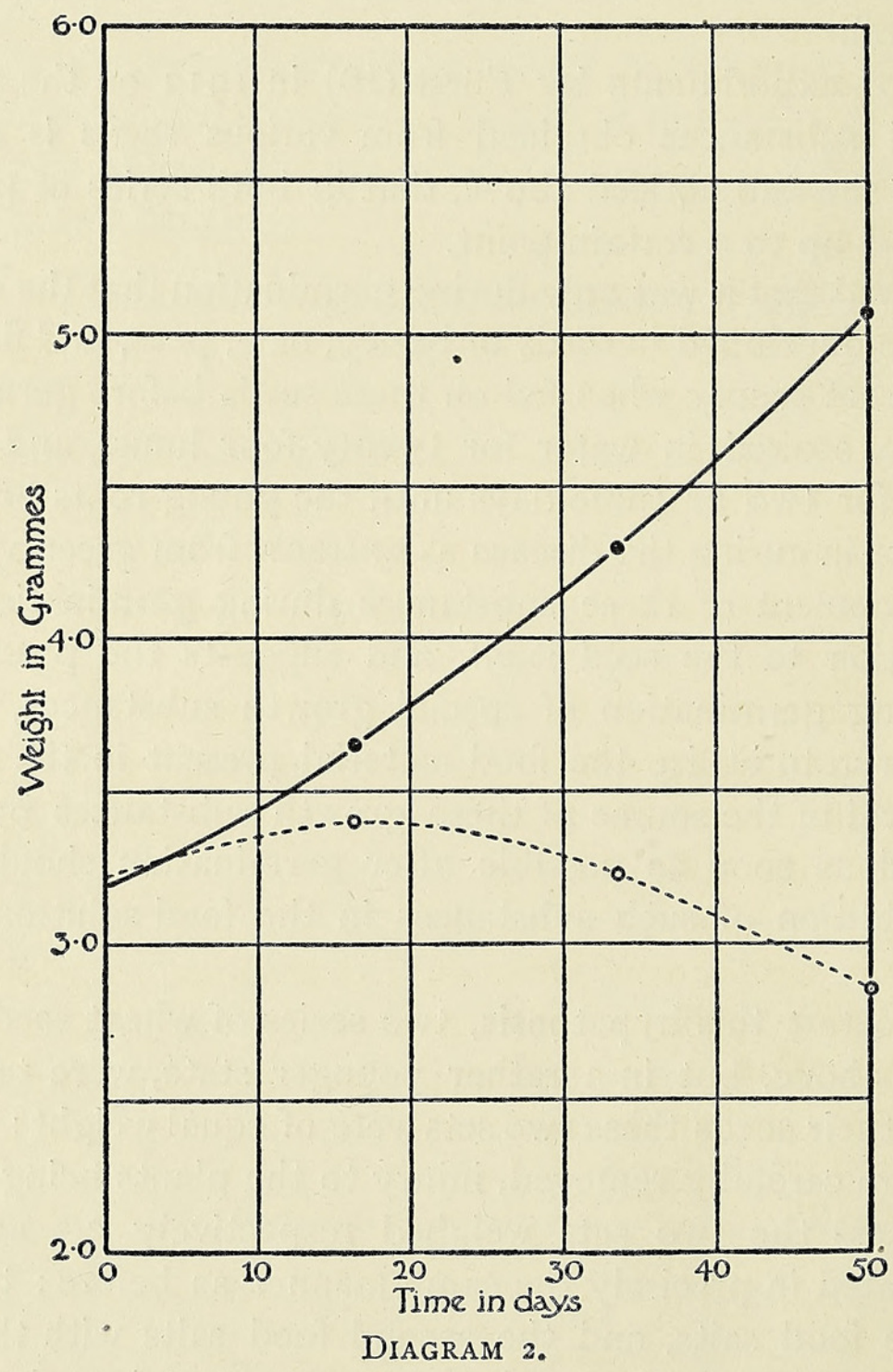

In this experiment the plants growing in pure food solution made no growth beyond the small amount which could be accounted for by the 
traces of the growth substances absorbed by the embryo before the seed was cut off. The plants with the silver fraction, however, show a progressive increase in weight, which was manifest by an increase in size whilst the experiment lasted. The result appears to support the view that during germination certain substances are developed which enable the embryo to utilize the food material present in the seed, and that these substances can be replaced in whole or part by the silver fraction from an extract of bacterized peat.

One striking fact connected, with these substances is that they are active in extremely minute quantities, 0.35 part of the silver fraction per million parts of culture solution being sufficient to give the results quoted above.

The chief interest of these experiments centres round the possibility that the nutrition of a plant depends, not only upon the supply of mineral food constituents, but also upon a supply of certain accessory organic food substances, very small amounts of which are sufficient to supply the needs of the plant. During the early stages of growth of the embryo, these substances are supplied by the seed; later when the young plant is able to maintain itself, they are obtained from the humus of the soil.

How far this theory is a correct one can only be decided by further careful experiments which are now in progress. In view, however, of the growth results obtained by ordinary water-culture methods in the laboratory it must be noted that the above results were only obtained by using chemically pure salts and physiologically pure distilled water, thus avoiding any possible inclusion of traces of soluble organic matter. Care was also taken to prevent any bacterial or algal contamination of the culture solutions.

Nothing definite can yet be stated as to the nature or composition of these growth-stimulating substances, but experiments in progress appear to indicate that they resemble more closely the accessory food factors of Hopkins than the vitamines of Funk.

In conclusion, I wish to express my indebtedness to Miss Mockeridge, B.Sc., for her valuable assistance with the chemical part of this investigation ; also to thank Mr. Watson of the Royal Gardens, Kew, and Mr. Hales of the Chelsea Physic Garden, for their kindness in carrying out a series of pot experiments. 


\section{BIBLIOGRAPHY.}

1. Krzemieniewski : Bull. Acad. Sci. Cracovie, I908.

2. Hutchinson and Miller: Centralbl. f. Bakt., vol. xxx, igi I.

3. Bottomley : Report Brit. Assoc., Trans. Sect. K, I9I 2.

4. - Journ. Roy. Soc. Arts, vol. lxii, I9I4.

5. Osborne and Mendel: Carnegie Inst. Publication i56, i9i i.

6. Hopkins : Journ. of Physiol., vol. xliv, I9I2.

7. COOPER and FUNK: Lancet, I9II.

8. Funk : Journ. of Physiol., vol. xlv, I9 2.

9. Hopkins : Brit. Med. Journ., vol. ii, I9I3.

10. FürST: Zeitschr. f. Hyg. u. Infekt., vol. lxxii, IgI2. 


\section{$2 \mathrm{BHL}$ Biodiversity Heritage Library}

Bottomley, W. B. 1914. "The significance of certain food substances for plant growth." Annals of botany 28, 531-540.

https://doi.org/10.1093/oxfordjournals.aob.a089520.

View This Item Online: https://www.biodiversitylibrary.org/item/236856

DOI: https://doi.org/10.1093/oxfordjournals.aob.a089520

Permalink: https://www.biodiversitylibrary.org/partpdf/320038

\section{Holding Institution}

Smithsonian Libraries

\section{Sponsored by}

Biodiversity Heritage Library

\section{Copyright \& Reuse}

Copyright Status: Not in copyright. The BHL knows of no copyright restrictions on this item.

This document was created from content at the Biodiversity Heritage Library, the world's largest open access digital library for biodiversity literature and archives. Visit BHL at https://www.biodiversitylibrary.org. 